\title{
Inactivation of Escherichia coli 0157:H7 by Essential Oil from Cinnamomum zeylanicum
}

\author{
Ouafae Senhaji ${ }^{1}$, Mohamed Faid ${ }^{2}$ and Ichraq Kalalou ${ }^{2}$ \\ ${ }^{1}$ Laboratory of Research and Medical Analysis of Gendarmerie Royale; ${ }^{2}$ Hassan II, Institute of Agronomy and Veterinary, \\ Medicine Department of Food Engineering and Technology; Rabat, Morocco
}

\begin{abstract}
Escherichia coli 0157:H7 is a pathogen strain, which causes hemorrhagic colitis, hemolytic uremic syndrome and thrombotic thrombocytopenic purpura in humans. The control of bacterial cells in foods is an important factor to reduce foodborne diseases due to $E$. coli $0157: H 7$. Assays to inactivate $E$. coli $0157: H 7$ were carried out by using the cinnamon oil obtained by steam distillation for 6 hours. When $E$. coli $0157: H 7$ cells were incubated at $37^{\circ} \mathrm{C}$ for 2 hours in the presence of $0.025 \%$ of the essential oil from cinnamon, a dramatic decrease was observed in the viable counts (from $10^{7}$ to $3.10^{4} \mathrm{CFU} / \mathrm{mL}^{-1}$ ). In the presence of $0.05 \%$ of the oil, most of cells were killed after $30 \mathrm{~min}$, suggesting that the antimicrobial activity of essential oil is bactericidal against $E$. coli. The minimal inhibitory concentration of the essential oil from cinnamon was around $625 \mathrm{ppm}$ against $E$. coli 0157:H7 and E. coli ATCC 25921, around $1250 \mathrm{ppm}$ against E. coli ATCC25922 and around $2500 \mathrm{ppm}$ against E. coli ATCC11105.
\end{abstract}

Key-Words: Antimicrobial effect, bactericidal, essential oil, Cinnamon, E. coli O157:H7.

More than 1340 plants are known to be potential sources of antimicrobial compounds, but few have been studied [1]. Several other works have examined the effect of compounds isolated from essential oils extracted from plants on fungi and bacteria [2]. It has been known, since the ancient times, that spices and their essential oils have varying o of antimicrobial activities [3-7]. Many publications have documented the antimicrobial activity of cinnamon, clove and oregano oils against different microbial species [8-10]. The major antimicrobial components of spices and their essential oils are eugenol in cloves, cinnamic aldehyde and eugenol in cinnamon, carvacrol and thymol in oregano. The antimicrobial activity of some essential oils components against foodborne pathogens, including mycotoxin-producing fungi, has also been tested [11-13]. More recently, plant extracts have been developed and used in foods as natural antioxidants [14] and/ or antimicrobials [15]. The first objective of the present study was to determine the antimicrobial activity of essential oil from cinnamon against various Escherichia coli strains. These saprophytic strains may perform essential functions for the host, but a few strains are pathogenic, which cause distinct diarrhea syndromes. Among them, are enteropathogenic, enteroinvasive, enterotoxigenic and enterohemorrhagic. $E$. coli O157:H7 is a pathogen, which causes hemorrhagic colitis, hemolytic uremic syndrome and thrombotic thrombocytopenic purpura in humans [16].

\section{Materials and Methods \\ Essential Oil Distillation \\ Bark of Cinnamomum zeylanicum was obtained from retail. The essential oil of Cinnamomum zeylanicum was}

Received on 24 August 2006; revised 8 December 2006.

Address for correspondence: Dr. Senhaji O. Laboratoire de Recherche et d'Analyses Médicale de la Gendarmerie Royale, Av. Ibn Sina AgdalBP n o 8087 Rabat. Maroc. E-mail: senhajiwafae@yahoo.fr. Phone: 21267466158-Fax: 21237670058.

The Brazilian Journal of Infectious Diseases

2007;11(2):234-236. (C) 2007 by The Brazilian Journal of Infectious Diseases and Contexto Publishing. All rights reserved. obtained by extracting for 3 hours cinnamon barks by steam distillation.

\section{Steam Distillation}

Fresh plants were steam to isolate their essential oils. Amount of 100 to $150 \mathrm{~g}$ of plant was introduced in the distillation flask $(1 \mathrm{~L})$, which was connected to the steam generator via a glass tube and to a condenser to retrieve the oil. This was recovered in a funnel tube. Steam was applied for 3 hours, the recovered mixture was allowed to settle and the oil was withdrawn.

The oil was diluted in dimethyl sulfoxide (DMSO) and used for the antimicrobial activity test.

\section{Strains Used}

Escherichia coli O157:H7, Escherichia coli ATCC 25921, Escherichia coli ATCC25922 and Escherichia coli ATCC11105, were spot inoculated and incubated at $37^{\circ} \mathrm{C}$ for 24 hours. A control plate of the medium was inoculated in the same condition as the assays, but no extract was added.

\section{Diffusion Method}

A cell suspension was prepared from the stoke culture in saline water. This was diluted to $1 / 10$ and $0.1 \mathrm{~mL}$ of the dilution was deposited into a sterile plate. The medium kept at $45^{\circ} \mathrm{C}$ in a water-bath. Then, it was poured on the suspension and the plates were shacked to get a homogenous culture concentration in the medium. The plates were allowed to solidify and wells with $4 \mathrm{mM}$ of diameter were cut aseptically into the medium with a glass tube. These were then filled with $10 \mu \mathrm{L}$ of $1 / 100$ dilution of the essential oil. DMSO and streptomycin were used as negative and positive control.

Determination of Minimal Inhibitory Concentration (MIC)

MICs of essential oil from Cinnamomum zeylanicum were performed using a broth microdilution test as recommended by NCCCLS M27-A [17]. The medium used was BHI (Brain and Heart Infusion: Sanofi Diagnostic Pasteur). Wells were inoculated with $10 \mu \mathrm{L}$ of the microbial suspension in saline 
water. The covered microplates were incubated overnight at $37^{\circ} \mathrm{C}$. Ten $\mu \mathrm{L}$ of $2-3-5$ Tripheyltetrazolium chloride (TTC) (Sigma) dissolved in sterile water were added aseptically to the microplate wells and incubated at $37^{\circ} \mathrm{C}$ for $10-30 \mathrm{~min}$. TTC was prepared to a final concentration of $0.4 \mathrm{mg} / \mathrm{mL}$. A similar experiment was carried out using DMSO instead of essential oil as a control.

Kinetic Destruction Pattern

The isolates were spot inoculated and incubated at $37^{\circ} \mathrm{C}$ for 24 hours. After that, the cells grew in liquid medium for 6 hours, to reach the logarithmic phase. Cells were then harvested by centrifugation and were resuspended in BHI broth containing $0.05 \%, 0.025 \%$ and $0.012 \%$ of essential oil from cinnamon. Each broth was inoculated with the selected strain dilution to give a final concentration of $10^{7} \mathrm{CFU} / \mathrm{mL}^{-1}$. The broths were incubated at $37^{\circ} \mathrm{C}$ for 2 hours with shaking. The final volume was $20 \mathrm{~mL}$ for each flask. Every $15 \mathrm{~min}, 1 \mathrm{~mL}$ from each flask was resuspended into $9 \mathrm{~mL}$ of $\mathrm{NaCl}$. The aliquots were dispensed into $9 \mathrm{~mL}$ of sterile peptone water at $0.1 \%$ for three consecutives dilutions. One $\mathrm{mL}$ for final dilution was resuspended into $9 \mathrm{~mL}$ of Muller Hinton Agar (MHA) (Bekinson Dikinson, UK) which kept at $45^{\circ} \mathrm{C}$. After solidification, the plates were incubated at $37^{\circ} \mathrm{C}$ for 24 hours. The viable counts were expressed at $\mathrm{CFU} / \mathrm{mL}^{-1}[18]$.

\section{Results}

Diffusion Method

Antimicrobial activity of essential oil from Cinnamomum zeylanicum was investigated against various $E$. coli strains
(Table 1). The essential oil showed a higher and a stronger antimicrobial activity than streptomycin, used as a control. Cinnamomum zeylanicum is one of the world's oldest spices that has been used as a natural preservative in food, beverage and cosmetic industries. Its oil has been reported to inhibit the growth and subsequent toxin production of Aspergillus parasitucus at $200-250 \mu \mathrm{g} / \mathrm{mL}^{-1}$ [11]. It has been reported that application of cinnamon revealed potent antimicrobial effects against Clostridium perfringens, Bacteroïdes fragilis and Bifidobacterium bifidus [19].

MIC of Essential Oil from Cinnamon Against Various Pathogenic E. coli (Table 2)

The antimicrobial activity of the essential oil from Cinnamomum zeylanicum and its MCI were determined in various E. coli strains. E. coli O157:H7 and E. coli ATCC25921 showed higher sensitivity than E. coli ATCC11105 and E. coli ATCC25922 to the essential oil from cinnamon. When streptomycin was used, E. coli O157:H7 and E. coli ATCC25922 showed higher sensitivity than E. coli ATCC25921 and E. coli ATCC11105. The MIC of the essential oil was $625 \mathrm{ppm}$ against E. coli strains O157:H7 and ATCC25921, 1250 ppm against strain ATCC25922 and 2500 ppm against strain ATCC11105.

This seems very interesting for the preservation of foods, since cinnamon is added as a flavoring agent [20].

During the last decade, consumer awareness about the food safety related with hormones, food additives, food preservatives, etc. had increased [21]. For this reason, many studies on the antimicrobial compounds from spices against

Table 1. Antimicrobial activities of essential oil from the bark of Cinnamomum zeylanicum against various E. coli strains

\begin{tabular}{lcccc}
\hline \multicolumn{4}{c}{ Inhibition zone (mm) } \\
\hline & ATCC 25921 & ATCC11105 & O157:H7 & ATCC25922 \\
\hline Oil & 25 & 20 & 28 & 22 \\
Streptomycin & 17 & 17 & 20 & 21 \\
DMSO & $\mathrm{R}$ & $\mathrm{R}$ & $\mathrm{R}$ & $\mathrm{R}$ \\
\hline
\end{tabular}

E. coli=Escherichia coli, DMSO=dimethyl sulfoxide; $\mathrm{R}=$ resistant.

Table 2. The minimal inhibitory concentration of essential oil from Cinnamomum zeylanicum against various E. coli strains

\begin{tabular}{lccc}
\hline \multirow{2}{*}{ Strains } & \multicolumn{3}{c}{ MICs } \\
\cline { 2 - 4 } & Oil & Streptomycin & DMSO \\
\hline ATCC25921 & $625 \mathrm{ppm}$ & $18 \mu \mathrm{g} / \mathrm{mL}$ & $\mathrm{R}$ \\
O157:H7 & $625 \mathrm{ppm}$ & $9 \mu \mathrm{g} / \mathrm{mL}$ & $\mathrm{R}$ \\
ATCC11105 & $2500 \mathrm{ppm}$ & $18 \mu \mathrm{g} / \mathrm{mL}$ & $\mathrm{R}$ \\
ATCC25922 & $1250 \mathrm{ppm}$ & $9 \mu \mathrm{g} / \mathrm{mL}$ & $\mathrm{R}$ \\
\hline
\end{tabular}

E. coli=Escherichia coli; $\mathrm{DMSO}=$ dimethyl sulfoxide; $\mathrm{R}=$ resistant; MIC=minimal inhibitory concentration.
Figure 1. Inhibitory effect of essential oil from Cinnamomum zeylanicum on the growth of Escherichia coli O157: H7.

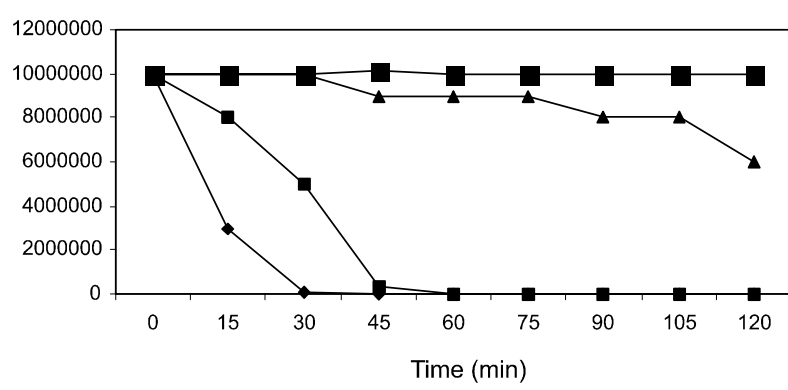

$\neg 0.05 \% \rightarrow-0.025 \% \rightarrow-0.012 \% \rightarrow-$ control 
foodborne pathogens have been reported. Recently, renewed interests in the use of spices as sources of antimicrobial compounds in foods are evident. When safety of synthetic additives is questioned, natural compounds of plant origin may appeal to the public.

\section{Kinetic Destruction Pattern}

Viable cells were counted during the culture in BHI media containing the essential oil in order to investigate whether the growth-inhibiting effect of essential oil on E. coli O157:H7 is attributable to bacteriostatic or bactericidal activity (Figure 1).

In the absence of essential oil, viable counts increased from $5 \times 10^{6} \mathrm{CFU} / \mathrm{mL}^{-1}$ of the initial counts to $4.710^{7} \mathrm{CFU} / \mathrm{mL}^{-1}$ at $37^{\circ} \mathrm{C}$ for 2 hours of cultivation.

No significant changes in the viable counts were observed in the presence of $0.012 \%$ of the compound during the growing time. However, addition of $0.025 \%$ of the compound in the media resulted in a dramatic decrease in the viable counts, which was $3.10 \mathrm{CFU} / \mathrm{mL}^{-1}$ after 2 hours of incubation. In the presence of $0.05 \%$ of compound, all the cells were killed after 30 min of incubation.

\section{Discussion}

The results of this study suggest that the antimicrobial activity of the essential oil from cinnamon is bactericidal.

Antimicrobial mechanisms of natural compounds found in herbs or spices have been discussed [22]. Thymol and carvacrol presented inhibitory effects on the growth of enteric bacteria (E. coli O157:H7 and Salmonella typhimurium). They have prominent outer membrane disintegration activity and they increased the permeability to ATP through cytoplasmic membrane. However, trans-cinnamic aldehyde exhibited neither outer membrane disintegrating activity nor depletion of intracellular ATP [23].

In conclusion, this study demonstrated that the essential oil from barks of Cinnamomum zeylanicum has excellent antibacterial activities. Therefore, it is beneficial to human health. It has the potential to be used for medical purposes and to be utilized as anti-bacterial additives in making paper products.

\section{References}

1. Wilkins K.M., Board R.G. Natural antimicrobial systems. In: Gould G.W. ed. Mechanisms of Action of Food Preservation Procedures. London: Elsevier, chapter 11, 1989.

2. Chao S.C., Young D.G. Screening for inhibitory activity of essential oils on selected bacteria, fungi and viruses. J Essent Oil Res 2000; $12: 630-49$.
3. Shelef L.A. Antimicrobial effects of spices. J Food Saf 1983;6:29-44.

4. Zaika L.L. Spices and herbs: their antimicrobial activity and its determination. J Food Saf 1988;9:97-118.

5. Beuchat L.R., Glden D.A. Antimicrobials occurring naturally in foods. Food Technolol 1989;43:134-42.

6. Ting E.W.T., Deibel K.E. Sensitivity of Listeria monocytogenes to spices at tow temperatures. J Food Saf 1992;12:129-37.

7. Juvan B.J., Kanner J., Schved F., Weisslowicz HFactors that interact with the antibacteral action of thyme essential oil and its active constituents. J Appl Bacteriol 1994;76:626-31.

8. Farag R.S., Daw Z.Y., Abo-Raya S.H. Influence of some spices essential oils on Aspergillus parasitucus growth and production of aflatoxins in a synthetic medium. J Food Sci 1989;54:74-6.

9. Hammer K.A., Carson C.F., Riley T.V. Antimicrobial activity of essential oils and other plant extracts. J Appl Microbiol 1999;86:985-90.

10. Inouye S., Wwatabable M., Nishiyama Y., Takeo K., Akao M., Yamaguchi H. Antisporulating and respiration-inhibitory effects of essential oils on filamentous fungi. Mycoses 1998;41:403-10.

11. Bullerman L.B., Lieu F.Y., Seier S.A. Inhibition of growth and aflatoxin production by cinnamon and clove oils, cinnamic aldehyde and eugenol. J Food Sci 1977;42:1107-9.

12. Kim J., Wei C.I., Marshall M.R. Antibacterial activity of some essential components against five foodborne pathogens. J Agri Food Chem 1995;48:2839-45.

13. Ultee A., Slump R.A., Steging G., Smid E.J. Antimicrobial activity of Carvacrol toward Bacillus cereus on rice. J Food Prot 2000;63:620-4.

14. Basaga H., Tekkaya C., Acikel F. Antioxidative and free radical scavenging properties of rosemary extract. Lebensm Wisst Technol 1997;30:34-142.

15. Hsieh P.C., Mau J.L., Huang S.H. Antimicrobial effect of various combinations of plant extracts. Food Microbiol 2001;18:3543.

16. Zottola E.A., Smith L.B. The microbiology of foodborne disease outbreaks: an update. J Food Saf 1991;11:13-29.

17. National Committee for Clinical Laboratory Standards. Methods for dilution antimicrobial susceptibility tests for bacteria that grow aerobically: Approved standard (5 $5^{\text {th }}$ ed). NCCLS document M7-A5. wayne PA : NCCLS, 2000.

18. Cox S.D., Mann C.M., Markham J.L., Gustafson J.E., Warmington J.R., Wyllic S.G. The mode of antimicrobial action of Malaleuca alternifolia (Tea Tree oil). J Appl Microbiol 2000;88:170-5.

19. Lee H.S., Ahn Y.J. Growth-inhibiting effects of Cinnamomum cassia barks-derived materials on human intestinal bacteria. J Agri Food Chem 1998;46:8-12.

20. Faid M., Bakhy K., Achad M., Tantaoui-Elaraki A. Almond paste: physicochemical and microbiological characterization and preservation with sorbic acid and cinnamon. J Food Prot 1995;58:547-50.

21. Brewer M.S., Sprouls G.K., Russon C. Consumer attitudes toward food safety issues. J Food Saf 1994;14:63-76.

22. Brul B, Coot P. Reservative agents in foods mode of action and microbial resistance mechanisms. Inter J Food Microbiol 1999;50:1-17.

23. Helander I.M., Alakomi H.L., Larva-Kala K., et al. Characterization of the action of selected essential oil components on Gramnegative bacteria. J Agri Food Chem 1998;46:3590-5. 